\title{
Komplikasyon mu? Malpraktis mi?
}

\section{Complication or Malpractice?}

\author{
Ünal Kuzgun
}

Şişli Etfal Hastanesi, Ortopedi ve Travmatoloji Kliniği, İstanbul

O rtopedi ve Travmatoloji uygulamalarımızda son yıllarda en çok konuşulan konulardan birisi de komplikasyon ve malpraktis kavramlarıdır. Meslektaşlarımızın hiç karşılaşmak istemedikleri, ama normal hayatın akışı gereği el attığımız her vakada tanıdan başlayıp cerrahi tedaviye ve sonrasına giden süreçte bu arzulanmayan, istenmeyen, beklenen ya da beklenmeyen durumlarla karşılaşmak olasıdır. Özellikle istenmeyen durum malpraktis olarak değerlendirildiğinde bunun ceza ve tazminat yaptırımlarının ortaya çıkması konunun önemini çok daha arttırmaktadır.

Komplikasyonun kelime anlamı karmaşadır. Genel olarak bir hastalığın tedavisi sırasında oluşan başka patolojik olaylar ve hastalıkların ortaya çıkmasını ifade eder. Komplikasyonu ayrıca iki ayrı tanımla da ifade edebiliriz:

1) Tanı, tıbbi tedavi veya cerrahi girişim sonrasında ortaya çıkan herhangi bir hoşa gitmeyen durum,

2) Hastanın hastalığı sırasında veya hastalığın tedavisi sırasında beklentilerin dışında ortaya çıkan gelişme.

Hukuki kavram olarak komplikasyon izin verilen risk anlamını taşır. Burada hastaya, tedaviye başlamadan önce ortaya çıkabilecek olumsuz durumlar anlayabileceği bir dille anlatılır ve daha sonra yazılı bir belge ile imza altına alınır (bilgilendirilmiş ve aydınlatılmış onam). Hukuk açısından bu belgelerin usulüne uygun alınması hastanın olası risklerle ilgili olarak bilgilendirildiği ve onayının alındığı anlamına gelmektedir.
Tüm bu verilerin ışığı altında;

- günümüzde kabul edilebilir,

- cerrahi ve yapılan tedavi ile direkt ilişkili olan,

- hastayı etkileyen,

- sekel, yetersiz tedavi ve ihmal eylemleri haricinde yer alan,

- tıp literatüründe beklenti oranı düşük olarak ortaya çıkabilen ve

- hasta tarafindan bilinen, istenmeyen durumlara komplikasyon tanımı içerisinde yer verilmelidir.

Malpraktis kelime anlamı olarak kötü pratik, kötü uygulama demektir. Bu tanım her meslek için geçerlidir; örneğin bir hakimin, avukatın ya da bir mimarın da mesleki uygulamaları sırasında hata ve kusurları olabilir. Nedense, malpraktis terimi en çok tıp alanında kullanılmaktadır. Burada terimi "tıbbi malpraktis" olarak değerlendirenler olduğu gibi hekimlikte hatalı ve kusurlu uygulama olarak nitelendirmek, kötü uygulamaya tercih edilmelidir. Halk arasında ise bu durum "doktor hatası" olarak nitelendirilmektedir. Ancak, sağlık alanında hastaya doktor dışında el atan diğer tüm sağlık çalışanları da bu olumsuz durumla karşılaşabilirler.

Tıbbi malpraktisin tanımında komplikasyon kadar fazla sorun yaşanmamakla beraber, uygulamada eylemin hata veya kusur olarak değerlendirilmesinde farklı görüşler ortaya çıkabilmektedir. Türk Tabipler Birliği tarafindan "tıbbi malpraktis", "bilgisizlik, deneyimsizlik ya da ilgisizlik nedeni ile hastanın zarar görmesi" olarak tanımlanmıştır.

- Illetişim adresi: Prof. Dr. Ünal Kuzgun, Merkez Mah. Nakiye Elgün Sok. 46 Şişli, İstanbul

Tel: 0532 - 3655037 e-posta: ukuzgun@yahoo.com

- Geliș tarihi: 19 Aralık 2018 Kabul tarihi: 19 Aralık 2018 
Dünya Tabipler Birliği'nin 1992 yılındaki 44. genel kurulunda tıbbi uygulama hataları "hekimin tedavi sırasında standart uygulamayı yapmaması, bilgi beceri eksikliği veya hastaya tedavi vermemesi ile oluşan zararlar" olarak tanımlanmıştır.

Mesleki uygulamalarda en sık rastladığımız tıbbi uygulama hatalarından birisi, komplikasyon ortaya çıtığında yerinde ve zamanında gerekli önlemlerin alınmaması ve bunun bir tıbbi hataya dönüşmesidir. Böyle bir durumun daha sonra bilirkişi düzeyinde değerlendirilmesinde en önemli husus ise tıbbi kayıtlardır. Komplikasyonun yönetimi sırasında gerekli kayıtların tutulmaması, gereken tedbirlerin alınmış olması ifade edilse de kayıtlarda görülemediğinde hekim açısından olumlu yönde değerlendirilememektedir.

Malpraktise yol açan eylemler kısaca şunlardır:

- Tanı koyma sürecinde yapılan hatalar (gecikme, atlama vb).

- Tedavide yapılan hatalar.

- İşleme bağlı hatalar (yanlış yöntem seçilmesi doğru yöntemin yanlış uygulanması).

- İlaç doz yöntem uygulama hataları (gereksiz aşııı tedavi).

- Taraflı ilaç, tedavi seçimi.

- Ihmale bağlı hatalar (doğru işlemi yapmama, gecikme).

- Uygulamaya bağlı hatalar (doğru işlemleri yanlış uygulama).

- Tedavi ve takip ile ilgili özel bilgilerin verilmemesi.

- Gerekli profilaksi yapılmaması veya yanlış yapılması.

- Komplikasyonların tanınamaması ve/veya yetersiz tedavisi.

İlem hatalarını ise şöyle belirtebiliriz:

Hastalar, tedavi süresince ve tıbbi girişim sonrasında belirli sürelerle izlenmelidir. İzlem yatan hastalar için 24 saat gereklidir. Taburcu edilen hastalar için protokollerde belirlenen sürelerdir. Hekimlerin gözlem/ izlemde sorumlulukları, hastalığın seyri ve tedavinin izlemi, öngörülen olumsuz sonuçların takip edilmesidir.

Komplikasyonların ve tıbbi hataların önlenmesinde branşımızla ilgili standartların belirlenmesi önem taşımaktadır. Bu standartlar genel anlamda daha önce yayımladığımız Sağlık Hukuku el kitabında belirtilmeye çalışılmıştır. Bölümümüz eklem ve artroplasti cerrahisi ile ilgili standartlara özellikle değinilmiştir.

\section{ORTOPEDI VE TRAVMATOLOJIDE STANDARTLAR}

Genel ortopedi açısından bu başlı̆ıın altını doldurmak zordur ve çok kapsamlıdır. Her bir hastalık ve her bir kırık veya birden çok kırıklı hastada genel kabul görmüş yapılması gereken işlemler sıralandığında, geniş hacimli bir ortopedi ve travmatoloji kitabı yazılmış olur. Bu yapılmış olsa da, en klasik uygulamalarda bile farklılıklar olduğu için tartışmalara yol açabilir. Standartları belirlemede yöntem esastır.

Türk Ortopedi ve Travmatoloji Eğitim Konseyi (TOTEK), standartları belirleme için uğraş vermiş, sonrasında Sağlık Bakanlığı Sağlık Eğitimi Genel Müdürlüğü bünyesinde oluşturulan Eğitim Müfredat Komisyonları da çalışmalarını TOTEK'in yaptığı çalışmaları baz alarak sürdürmüştür. Bu standartlar, bu çalışmalar göz önünde tutularak belirlenmiştir. Tüm ortopedi ve travmatoloji konularıla ilgili standartlar Sağlık Hukuku El kitabından edinilebilir. Bu bölüm kapsamında, eklem ve artroplasti cerrahisinin standartları üzerinde durulmuştur. Ortopedi ve Travmatoloji uzmanı için bilgi ve beceriler tanımlanmıştır (Total Diz Protezi [TDP] ile ilgili olarak kısaltılmıştır).

\section{Ortopedi ve Travmatolojiye ait BILLGiLER}

A. Bireysel olarak rahatlıkla uygulayabileceği ve çok iyi düzeyde bilinmesi gereken bilgiler:

- Ekstremite akut dolaşım ve nörolojik bozuklukları.

- Temel sıvı-elektrolit tedavisi.

- Kas iskelet sistemi inflamatuvar, enfeksiyöz hastalıkları.

- Dejeneratif eklem hastalıkları.

- Ameliyat öncesi ve sonrası bakım.

- Temel adli tıp bilgileri mesleği ile ilgili yasal düzenlemeler.

B. Yeterli düzeyde sahip olduğu veya iyi düzeyde bilmesi gereken bilgiler:

- Kas iskelet sistemi anatomisi, fizyolojisi ve biyomekaniği.

C. Başkasından izlediği ya da kuramsal olarak bilmesi gereken bilgiler:

- Az görülen ortopedik hastalıklar.

- İleri düzey ortopedik girişimler (revizyon cerrahisi). 


\section{Ortopedi ve Travmatolojiye ait BECERILER}

1. Bireysel olarak rahatlıkla uygulayabileceği ve çok iyi bilmesi gereken beceriler:

\section{o Acil durumlarda}

- Temel osteosentez teknikleri.

- Ekstremitenin nörolojik ve damarsal bozuklukları.

- Kompartman sendromu.

- Kas iskelet sitemi enfeksiyon ve inflamatuvar durumları.

o Acil olmayan durumlarda

- Kas iskelet sistemi dejeneratif ve enfeksiyöz hastalıkları

- Ameliyat öncesi ve sonrası bakım.

- Sık görülen iskelet sistemi deformasyonları.

- Diyabetin ortopedik komplikasyonları.

- Osteoporoz ve ortopedik komplikasyonları.

- Koruyucu ortopedi.

- Eklem ponksiyonları.

o Temel ve sık ameliyatları uygulayabilme

- Menisküs yaralanmaları artroskopi teknikleri.

- Diz ve kalça osteoartriti tedavileri.

2. Yeterli düzeyde deneyimi olması veya iyi düzeyde bilmesi gereken beceriler:

- Eklem içi kırıkların açık ve kapalı tedavisi.

- Büyük eklem artrodezi.

- Ön çapraz bağ tamiri.

3. Başkasından izlediği ya da kısmen bilmesi gereken beceriler:

- Kalça ve diz protezi revizyon cerrahileri.

- Diz eklem dışı artroskopileri.

- Adolesan ve erişkin kalça ve pelvik osteotomileri.

Sağlık Eğitimi Genel Müdürlüğü de TOTEK çaIsşmalarını esas alarak 11 ana başlık belirlemiştir. Bunlardan bölümümüzle ilgili olarak şunlar yer almaktadır:

\section{Temel Kavramlar ve Uygulamalar:}

- Lökomotor sistemdeki temel anatomik oluşumların yaralanma mekanizmalarını, iyileşme süreçlerini ve iyileşmeye etki eden faktörleri öğrenir.

- Klinik cerrahi anatomiyi öğrenir.

- Biyomateryalleri öğrenir.

- Biyomekaniği öğrenir.

- Görüntüleme yöntemlerini öğrenir.

- Preoperatif, intraoperatif ve postoperatif hastaya genel yaklaşımı öğrenir.

\section{Erişkin Eklem Rekonstrüksiyonu:}

- Diz eklemi primer osteoartrozunu bilir ve yönetir.

İskelet Sistemi Enfeksiyonları ve Metabolik Hastalıklar:

- Yumuşak doku enfeksiyonlarını bilir ve yönetir.

- Septik artriti bilir ve yönetir.

- Osteomiyeliti yönetir.

\section{Spor Hekimliği:}

- Diz sorunlarını yönetir.

Illetişim Becerileri, Çalışma esasları, Etik ve Medikolegal Konular:

- Hasta hekim ilişkisini yönetir.

- Tıbbi etiğe uyar.

- Bilimsel araştırmayı yönetir.

- Bilimsel etiğe uyar.

- Adli olguları yönetir.

Standartların daha ileri düzeyde belirlenmesinde branş derneklerine görev düşmektedir. Tedavi protokolleri ve profilaksi şemalarının her bir hastalık tanı ve tedavisi için belirlenme çalışmaları komplikasyon ve malpraktis olaylarının değerlendirilmesi sürecinde bilirkişilere de yol gösterici olacaktır. Bugüne kadar konu ile ilgili olarak bazı girişimlerde bulunulmuştur (örn; tromboemboli profilaksisi). Bunların artarak devamının çok yararlı olacağı kuşku götürmez.

Uygulamalarda malpraktise yol açan en önemli hususlar, iletişim eksikliği ve tedavi vermemekten doğan kusurlar olarak görülmektedir. İletişim eksikliği ya da 
sağlıksız iletişimin en önemli nedeni ise bilgilendirilmiş onam ve aydınlatılmış onamın kurallara uygun alınmamasıdır. Uygulamada çoğu kez, kimi zaman hemşire kimi zaman ise asistanlar tarafindan, onam formları hastaya ameliyathane kapısında imzalattırılmaktadır. Aydınlatılmış onamdan amaç hastanın başına gelebilecek olası komplikasyonlardan bilgilendirilmesidir. Bu yapılmadığında hasta şikâyeti "Bana bunlar daha önceden bildirilseydi, ameliyat olmazdım." tarzında ortaya çıkmaktadır. Bu nedenle, hastanın gözünü korkutmak amacıyla değil, olası problemler ve ortaya çıkma olasılığı üzerinden hastayı aydınlatmak çok önemlidir.

Sağlıksız iletişimin bir önemli örneğini ise hekimlerin hastalarla yaptıkları konuşmalar oluşturmaktadır. Bir doktora muayene ve tedavi olan hastanın olası bir problemle karşılaşıp bu kez gittiği ikinci bir doktorun hastayla konuşması çok önemlidir. İkinci doktor adeta bir bilirkişi görevi görmektedir. "Bu ameliyatı kim yaptı?" "Seni yanlış ameliyat etmişler." "Hastalığını yanlış teşhis etmişler, geç kalmışlar." tarzındaki ifadeler, adeta hasta ve hasta sahiplerinin eline pimi çekilmiş bir el bombası vermek gibidir. Hasta şikâyet dilekçelerinde en çok gördüğümüz husus da maalesef budur. "Gittiğim doktor dedi ki..." diye başlayan şikâyet dilekçeleri ile dava süreçleri başlamaktadır.

Komplikasyon oluştuğunda erkenden tanımak ve gerekli önlemleri almak da önemli bir husustur. Buradaki gecikmeler ve tanımamalar, gerekli tedavi verilemediğinden malpraktise dönüşebilmektedir.

Tanı ve tedavi sürecinde ortaya çıkan komplikasyon ya da malpraktisin tanımlanmasında en önemli görev bilirkişilere düşmektedir. Bilirkişiler ise kararlarını dosya incelemesi ile vermektedirler. Bu durumda, tıbbi kayıtlar son derece önem arz etmektedir. Dava süreçlerinde esas alınan ise dosya kayıtlarıdır. Uygulamada çeşitli nedenlerle, kayıtların tutulmasında hekimlerin gereken özeni gösteremedikleri de maalesef gözlenmektedir. Hastanelerdeki bilgisayar programlarının bilimsel kayıt olmaktan ziyade güvenlik kurumlarından fatura tahsilatına yönelik olduğu görülmektedir. Bu kayıtları, yoğunluk nedeni ile uygulamada sekreterler tutmaktadır. Bu da çok önemli bir eksiklik nedenidir. Hangi kurumda çalışırsa çalışsın bir ortopedistin tanı ve tedavi kadar önem vermesi gereken husus, kayıtların sağlıklı tutulmasını sağlamak olmalıdır. Sağlıklı tutulan ve istendiğinde ortaya konan kayıtlar bir hekimin en önemli savunma araçlarıdır.
Değerlendirmede bir diğer önemli husus ise bilirkişilerin niteliğidir. Geçmişte, sadece bir ortopedi uzmanı olmak bilirkişi olmak için yeterli idi. Ama geldiğimiz aşamada ortopedinin de birçok alt dala ayrıldığı ve bu dallarda uzmanlaşmış meslektaşlarımızın o konuyu en iyi bilen kişiler olduklarını biliyoruz. Bugün, mahkemelerimizin en çok müracaat ettiği bilirkişilik kurumlarının başında gelen adli tıp komisyonlarında onlarca çeşitli branştan hekim olmasına rağmen, bir tek ortopedist bulunmakta ve her tür vaka için görüş belirtebilmektedir. Adli tıp dışında da, mahkemelerin adalet komisyonlarında bilirkişilik görevi almak için eskiden sadece uzmanlık belgesi yeterli iken, şimdi bilirkişilik sertifikası alma koşulu getirilmiştir. Bu sertifikaların alınabilmesi için bilirkişilik kurslarına devam şartı da getirilmiştir. TOTBiD'in Türk Tabipler Birliği (TTB) ile yaptığı işbirliği sonucu, bu kursların ilki geçen yıl Ankara'da düzenlenmiş ve 25 meslektaşımız bilirkişilik sertifikalarını almışlardır. Burada öncelikle, bilirkişi görüşlerinin raporlanmasında uyulacak kurallar öğretilmektedir. Keza, mahkemelerin üniversiteler bünyesinde üç profesörden oluşacak bir heyeti görevlendirerek görüş alması da imkân dahilindedir. TOTBiD bünyesinde 2008 yılında kurulmuş olan Sağlık Hukuku Kurulu ise TOTBiD'e üye meslektaşlarımızın müracaatları halinde dosya üzerinden gerekli incelemeleri yaparak ve uzmanlık derneklerimizden görüşler alarak raporlar vermektedir. Bu görüşler de mahkemeler tarafindan dikkate alınmaktadır. Kanımızca, branşımızla ilgili sorunlarda en sağlıklı tıbbi görüşler bu konuda gerçekten uzmanlaşmış kişilerden alınmalıdır.

Yanlış taraf cerrahisi ya da operasyon sahasında tampon, tıbbi materyal vb. unutmak gibi hususlar, tartışmasız malpraktis olarak kabul edilmektedir. Tam bir ekip çalışması olan tıbbi uygulamalarda, bu nedenle, ekipteki herkesin gerekli özeni göstermesi son derece önemlidir. Ekibin başı ve yöneticisi olarak ortopedistin gereken hassasiyeti her açıdan göstermesi, komplikasyon ve malpraktis oranlarını azaltacaktır.

\section{KAYNAKLAR}

1. Hakeri H. Tıp Hukuku. Ankara: Seçkin Yayıncılık; 2007.

2. Hancı IH. Malpraktis. Ankara: Seçkin Yayıncılık; 2005.

3. Kuzgun Ü, Varol N. Sağıık Hukuku El kitabı. Ankara: TOTBiD Yayınları; BAYT Bilimsel Araştırmalar Basım, Yayın ve Tanıtım Ltd. Şti.; 2013.

4. Polat O. Tıbbi Uygulama Hataları. Ankara: Seçkin Yayıncılık; 2005. 